\title{
FAKTOR-FAKTOR YANG MEMPENGARUHI KINERJA BUMDES DILE DALAM PENGELOLAHAN UNIT-UNIT USAHA
}

\section{Fidentus Didakus Darma Saputra}

Sekolah Tinggi Pembangunan Masyarakat (STPM) Santa Ursula Nusa Tenggara Timur, Indonesia

Email: denssaputra153@gmail.com

\begin{abstract}
Abstrak
Tidak berjalannya unit usaha BUMDes tentunya sangat dipengaruhi oleh bermacam-macam faktor. Baik secara internal maupun eksternal. Faktor-faktor pengahambat itulah yang membuat BUMDes Dile mengalami kemacetan selama beberapa tahun terakhir semenjak dibentuk tahun 2016. Unit usaha yang masih eksis hanyalah unit usaha sewa tenda dan kursi. Sedangkan kedua unit usaha lain mengalami kendala. Peneliti sangat memfokuskan perhatian kepada faktor - faktor yang mempengaruhi kinerja BUMDes Dile. Penulis melakukan kajian deskriptif kualitatif untuk menggambarkan Kinerja Bumdes Dile Dalam Implementasi Program Unit Usaha. Jenis penelitian ini adalah penelitian deskriptif kualitatif. Teknik pemilihan subyek adalah teknik purposive. Teknik pengumpulan data yang digunakan penulis adalah observasi, wawancara, dan dokumentasi, Teknik analisis data yang digunakan penulis adalah dilakukan secara interaktif terdiri dari reduksi data (data reduction), penyajian data (data display), dan conclusion Drawing/Verification. BUMDes Dile tidak berjalan dikarenakan beberapa faktor, yaitu kapasitas sumber daya manusia yang tidak maksimal dalam mengelola dikarenakan masih terdapat persoalan internal yang belum selesai. Persoalan internal itu adalah SK pengurus yang belum dibuat, sehingga pengurus kehilangan legitimasi dari masyarakat. Pelaporan pelaksanaan program yang tidak di buat dari tahun 2018 sampai sekarang. Dan pelaksanaan peningkatan keterampilan pengurus melalui DIKLAT yang tidak efektif dan efisien. Semua temuan ini kemudian mempengaruhi kinerja BUMDes Dile yan mengalami penurunan kualitas dari tahun ke tahun.
\end{abstract}

Kata Kunci: kinerja; BUMDes; implementasi

\section{Abstract}

The failure of the BUMDes business unit is of course very much influenced by various factors. Both internally and externally. These inhibiting factors have caused BUMDes Dile to experience obstacles for the last few years since it was formed in 2016. The only business units that still exist are tent and chair rental business units. Meanwhile, the two other business units encountered problems. This Research focus on the factors that affect the performance of BUMDes Dile. The author conducted a qualitative descriptive study to describe the Performance of Bumdes Dile in Business Unit Program Implementation. This type of research is a qualitative

How to cite:

E-ISSN: Published by:
Saputra, Fidentus Didakus Darma (2021) Faktor-Faktor yang Mempengaruhi Kinerja BUMDES Dile Dalam Pengelolahan Unit-Unit Usaha. Syntax Literate: Jurnal Ilmiah Indonesia. 6(7). http://dx.doi.org/10.36418/syntax-literate.v6i7.3501 $2548-1398$ Ridwan Institute 
descriptive study. The subject selection technique is purposive technique. The data collection techniques used by the author are observation, interviews, and documentation. Data analysis technique is carried out interactively consisting of data reduction, data display, and conclusion Drawing / Verification. BUMDes Dile is having stagnancy due to several factors, namely the capacity of human resources that is not optimal in managing it because of internal problems that have not been resolved. The internal problem is the management decree that has not been made, so that the management loses legitimacy from the community. Program implementation reports that have not been made from 2018 to the present. And ineffective and efficient implementation of the management skills improvement through DIKLAT. All these findings then affect the performance of BUMDes Dile which has decreased in quality from year to year.

Keywords: performance; BUMDes; implementation

\section{Pendahuluan}

Sampai dengan 31 Mei 2018, realisasi anggaran dana desa yang telah disalurkan dari Rekening Umum Kas Negara (RKUN) ke Rekening Umum Kas Daerah (RKUD) tercatat sebesar Rp 20,66 triliun (Andri Donal Putera, 2018). Direktur Jenderal Pembangunan Daerah Tertinggal (Dirjen PDT) Samsul Widodo menjelaskan, dana desa pada tahun 2019 diharapkan naik menjadi Rp 85 triliun. Dengan demikian, jika angka ini naik, maka per desa akan mendapat Rp1,2 miliar hingga Rp1,3 miliar per tahun (Firmansyah, 2018).

Pemberlakuan otonomi daerah menjadi momentum bagi perbaikan kualitas pembangunan perdesaan yang diperkuat melalui pemberlakuan Undang-Undang Nomor 6 Tahun 2014 tentang Desa. Berdasarkan perundangan tersebut, pembangunan desa dianggap sebagai upaya untuk memperkuat ketahanan desa melalui pemberdayaan masyarakat serta pengembangan potensi yang dimiliki (Aini, 2020). Agar dana desa tidak sekedar dihambur-hamburkan untuk pengambangan fisik, maka jalan arternatif lain adalah melalui proses pemberdayaan. Dalam topik ini, proses pemberdayaan dilakukan melalui pemanfaatan Badan Usaha Miliki Desa (BUMDes) untuk meningkatkan ekonomi Desa. Dengan prinsip pengelolahan berbasis gotong royong, diharapkan BUMdes dapat membantu proses pemberdayaan di desa. Untuk meperkuat BUMDes selain dari sisi material seperti dana, peguatan kapasitas pengurus/sumber daya manusia menjadi penting. Oleh karena itu, paradigma pembangunan kawasan pedesaan perlu diubah dengan mengedepankan partisipasi aktif masyarakat dalam seluruh proses pembangunan (Aini, 2020).

Secara prinsip, pendirian BUMDes adalah merupakan perwujudan dari pengelolaan ekonomi produktif desa yang dilakukan secara kooperatif, partisipasif, emansipatif, transparansi, akuntabel, berkelanjutan (Madjodjo \& Dahlan, 2020). Dengan prinsip tersebut sebaiknya secara internal BUMDes harus dikelola oleh tengan-tangan yang profesional. Artinya kapasitas Sumber Daya Manusia harus berkompeten. Pada banyak kasus, BUMDes pada akhirnya "mati suri" karena hanya berharap pada penyertaan modal dari Dana Desa (DD). Padahal secara prinsip ketika BUMDes sudah 
mendapat bantuan dana, maka upaya yang dilakukan adalah mengelola dana tersebut menjadi sebuah produk/hasil yang menguntungkan secara ekonomis. Sehingga, penyertaan modal ditahun berikutnya tidak diperlukan lagi karena kekuatan dana dari BUMDes sendri sudah mencukupi.

(Peraturan Daerah Kabupaten Ende, 2014), yang menginstruksikan bahwa setiap desa yang ada di kabupaten Ende wajib ada. Persis sama seperti BUMDes milik masyarakat Dile di Kabupaten Ende. Memang pada prakteknya, kinerja BUMDes belum kelihatan jika dicermati secara menyeluruh. Tetapi pada kasus ini, kinerja BUMDes dapat digali berdasarkan porsi wilayah dari masing-masing desa yang telah menerapkan amanat UUDes terkait pembangunan melalui BUMDes. Dan berdasarkan analisa tersebut, fokus utama dari penelitian ini hanya sebatas ingin mencermati kinerja dari BUMDes Dile. Bukan pada studi komperatif dari desa-desa yang ada di Kecamatan Detusoko, meskipun desa tersebut sudah memiliki BUMDes.

BUMDes Dile di bentuk pada tahun 2016. Sampai saat ini, ada 3 program utama terkait unit usaha Desa yang diprogramkan BUMDes Dile. Ketiga unit usaha tersebut adalah, koperasi, pengadaan barang dan jasa (tenda dan kursi), dan pembelian komoditi (hasil bumi dari desa Dile). Meskipun secara regulasi ketiga program tersebut sudah dilegalkan, tetapi pada proses di lapangan hanya satu program yang notabenenya sedang berjalan.

Tidak berjalannya program yang sudah direncanakan, dapat menggangu perkembangan BUMDes Dile. Apa lagi, jika proses evaluasi tidak dilakukan rutin untuk mengontrol perkembangan level dari BUMDes Dile. Evaluasi itu bisa dilakukan bulanan, atau tahunan. Tergantung pada kesepakatan pengurus dan pemerintah Desa. Tidak lupa juga keterlibatan BPD (Badan Permusyawaratan Desa) sebagai perpanjangan tangan dari suara masyarakat Desa Dile. Ketiga komponen itu harus sejalan dalam proses kontrol atau monitoring, agar BUMDes Dile dapat bekerja sesuai dengan perintah UU.

Dalam pelaksanaannya BUMDes Dile selalu mengalami kendala. Meskipun secara struktur sudah cukup, tetapi semangat dan inovasi dari aparaturnya sering kali kendor. Sumber Daya Manusia selalu menjadi fenomena real dilapangan dalam proses implementasi kebijakan, terlebih khusus dalam hal ini, implementasi program kerja yang sudah direncanakan BUMDes Dile bersama stekholder lainnya. Karena itu kemudian Greer dan Carles dalam (Hardiyansyah, 2013) memuncullah istilah baru di luar H.R (Human Resources), yaitu H.C atau Human Capital (Hardiyansyah, 2013). Disini Sumber Daya Manusia dilihat bukan sekedar sebagai aset utama, tetapi aset yang bernilai dan dapat dilipatgandakan, dikembangkan dan juga bukan sebaliknya sebagai liability (beban, cost). Perspektik Sumber Daya Manusia sebagai insvestasi bagi institusi atau organisasi lebih mengemuka. Kualitas manusia sering kali memiliki level yang berbeda-beda jika ditinjau dari kompetensi dalam mengelola BUMDes. Dengan kompetensi yang berbeda itu, kemudian berpengaruh dalam terwujudnya program tersebut dilapangan. Pada perspektif ini, pengaruh intitusi atau sarana-prasarana tidak 
terlalu signifikan. Yang terpenting adalah bagaimana SDM itu dapat menjamin terlaksananya program atau regulasi yang telah dibuat.

Kepengurusan BUMDes, sudah terjadi dua kali pergantian. Ketua BUMDes tersebut dipilih pada saat awal pembentukan lambaga ini melalui musyawarah. Tetapi dalam perjalannya, digantikan oleh kepengurusan baru. Sampai sekarang belum ada pelantikan yang resmi, bukan hanya pada ketua BUMDes yang lama, tetapi juga pada ketua BUMDes baru. Hal ini menjadi kendala juga karena akan berpengaruh pada legitimasi dan kepercayaan public. Sehingga menjadi logis bahwa, pelaksanaan program unit-unit usaha ini seperti 'mandek' sebab pengurusnya belum memiliki legitimasi yang jelas dan dapat dipertanggung jawabkan.

Ada banyak faktor yang membuat BUMDes tidak berjalan maksimal. Salah satunya ada masalah yang terjadi antar organisasi yaitu BUMDes Dile dan pemerintah Kabupaten. Tidak hanya itu, terjadi permasalahan pada BUMDes sendiri, dimana ada ketidaksesuaian antar pengurus. Bahkan juga berdampak pada hubungan perangkat desa dan perangkat BUMdes. Konteks permasalahan tersebut sangat menarik minat peneliti. Tidak berjalannya unit usaha BUMDes tentunya sangat dipengaruhi oleh bermacammacam faktor. Baik secara internal maupun eksternal. Faktor-faktor pengahambat itulah yang membuat BUMDes Dile mengalami kemacetan selama beberapa tahun terakhir semenjak dibentuk tahun 2016. Unit usaha yang masih eksis hanyalah unit usaha sewa tenda dan kursi. Sedangkan kedua unit usaha lain mengalami kendala. Peneliti sangat menfukuskan perhatian kepada faktor apa yang kemudian menghambat kedua program tersebut tidak berjalan selama beberapa tahun terakhir.

Desa Dile adalah salah satu desa di kebupaten Ende yang letak geografisnya berada di pinggir jalan. Desa ini tidak terkumpul dalam satu wilayah, tetapi terpisah dalam empat (4) wilayah utama yaitu, dusun Tepetae, dusun Wolowege, dusun Wolongae, dan dusun Detubuga. Jika BUMDes diolah dengan baik, maka letak geografis desa Dile yang berada di pinggir jalan, dapat menambah nilai ekonomis masyarakat. Jalur jalan raya yang melintas di desa Dile adalah jalur pariwisata yang tujuan akhirnya adalah danau Kelimutu. Sehingga menjadi penting dalam membangun unit usaha yang sesuai dengan potensi di Desa Dile. Selain potensi itu, Dile juga menjadi wilayah dimana hasil buminya sangat bagus. Hasil bumi ini seperti, kemiri, kopi cengkeh, coklat, dan padi. Untuk potensi air, Desa Dile tidak kekurangan sebab terdapat banyak sumber mata air. Meskipun pada musim kemarau mata air tersebut tidak berhenti untuk mengalir. Potensi inilah yang harus dikelola untuk meningkatkan pendapatan asli desa (PAD) melalui BUMDes sebagai lembaga ekonomi dan sosial.

Berdasarkan latar belakang tersebut, diperlukan beberapa teori dan konsep untuk mendukung penelitian ini secara literatur. Konsep kebijakan publik (public policy) menurut (Riant, 2012) secara prinsip berasal dari dua aliran utama, yaitu pertama pemahaman Eropa Kontinental yang cenderung melihat bahwa kebijakan publik adalah turunan dari hukum, bahkan kadang mempersembahkan antara kebijakan publik dan hukum, utamanya hukum publik ataupun hukum tatanegara, sehingga melihatnya sebagai proses interaksi di antara institusi-institusi negara. Kedua, pemahaman Anglo- 
Saxonis, yang cenderung memahami bahwa kebijakan publik adalah turunan dari politik-demokrasi sehingga melihatnya sebagai sebuah produk interaksi antara negara dan publik. Artinya bahwa kebijakan publik dengan pendekatan Eropa Kontinental melihat kebijakan sebagai turunan dari hukum atau dengan kata lain kebijakan itu memiliki landasan yuridis yang kuat. Sedangkan kebijakan publik dengan pendekatan Anglo-Saxonis melihat kebijakan sebagai turunan dari politik atau dengan kata lain kebijakan di buat dan diselenggarakan dengan mempertimbangkan unsur politk seperti kepentingan, kekuasaan, jaringan, bahkan kebijakan itu sebaiknya dibuat dengan demokratis.

Ada juga beberapa teori pendukung seperti model analisis kebijakan, kinerja (pengukura kinerja), dan BUMDes. (Puwanto, Agus \& Ratih, 2015) menjelaskan bahwa kebijakan publik, dilihat dari perspektif intrumental yang merupakan alat untuk mencapai suatu tujuan yang berkaitan dengan upaya pemeritah mewujudkan nilai - nilai kepublikan. Artinya bahwa kebijakan publik dapat dikategorikan sebagai sebuah cara dari pemerintah untuk mensejahterahkan masyarakatnya melalui penerapan kebijakan. Disisi lain Dhunn dalam (Suharto, 2015) menjelaskan kebijkan publik bisa dianalisa menggunakan tiga (3) pendekatan. Pendekatan pertama adalah model prospektif yang menitikberatkan pada melihat implementasi sebelum kebijakan itu dilakukan. Kedua, model restropektif adalah model dimana melihat implementasi setelah kebijakan itu dilakukan. Dan ketiga, model integratif yang merupakan model yang lebih netral, dimana melihat implementasi kebijakan sebelum dan sesudah dilakukan. Pendekatan analisis kebijakan ini sebenarnya membantu untuk melihat fragmentasi kebijakan baik sesudah dan sebelum dilaksanakan. Tetapi untuk melakukan analisa yang baik, model integratif lebih cocok untuk memperoleh data secara komprahensif. Selain itu, kemungkinan untuk memberikan rekomendasi lebih baik karena data kebijakan dikumpulkan sebelum kebijakan itu diimplementasikan dan juga setelah kebijakan itu diimplementasikan.

Analisis berikut ditawarkan oleh Waeimer dan Vining (Riant, 2012) yang menjelaskan proses analisis kebijakan terdiri atas dua tahap utama, yaitu analisis masalah dan analisis solusi. Pada waktu proses analisis, secara pararel dilakukan pekerjaan pengumpulan informasi yang disebut kedua penulis (Riant, 2012) sebagai "dentifying and organizing relevant data, theories, and facts for assessing problem and predicting consequence of current and alternative policies. Pengumpulan informasi memberikan kontribusi baik pada analisis permasalahan maupun analisis solusi. Setelah proses analisis dilakukan tahap selanjutnya adalah melakukan komunikasi. Artinya, ketersediaan informasi baik dalam bentuk data, dokumentasi, bahkan hasil wawancara sangat berguna dalam meberikan analisa yang baik terhadap kebijakan baik yang sudah dilakukan dan belum dilakukan atau masih dalam tahap pembahasan. Setelah itu, dengan data yang baik dan informasi yang cukup, maka komunikasi bisa dilakukan antara orang atau antar instansi pemerintahan itu sendiri.

Untuk mengukur bagaimana kebijakan itu diterapkan dilapangan, maka memungkinkan adanya konsep Kinerja. Mangkunegara (Raihanah Daulay, Efri Kurnia, 
2019) menjelaskan bahwa kinerja merupakan hasil kerja secara kualitas dan kuantitas yang tercapai oleh seseorang karyawan dalam melaksanakan tugas sesuai dengan tanggung jawab yang diberikan kepadanya. Sedangkan Hakim (Raihanah Daulay, Efri Kurnia, 2019) menjelaskan bahwa kinerja sebagai hasil kerja yang dicapai oleh individu yang disesuaikan dengan peran atau tugas individu tersebut dalam suatu perusahaan pada suatu periode waktu tertentu, yang dihubungkan dengan suatu ukuran nilai atau standar tertentu dari perusahaan dimana individu tersebut bekerja. Menurut Spekle dan Verbeeten (Wahyuni, Taufik, \& Ratnawati, 2016) menyatakan bahwa sistem pengukuran kinerja merupakan kunci utama dalam mewujudkan manajemen sektor publik yang efektif, efisien dan akuntabel. Dari pendapat-pendapat tersebut dapat digaris bawahi bahwa sitem pengukuran kinerja sangat penting dalam mendorong organisasi atau instansi pemerintahan untuk terus berkembang sesuai dengan keadaan lingkungannya baik internal maupun eksternal. Pengukuran kinerja sendiri menjadi awal dalam memberikan rekomendasi-rekomendasi kepada instansi pemerintah untuk merevisi beberapa kekeliruan teknis yang berkaitan dengan pelayanan publik (Public Service).

Sihaloho dan Halim (Sofyani \& Akbar, 2013) menyarankan agar sebelum intansi pemerintah menjalankan suatu sistem pengukuran kinerja, maka peru untuk memperhatikan beberapa faktor internal organisasi supaya menghindari informasi yang tidak termanfaatkan atau agar pelaksanaan sistem pengukuran kinerja tersebut tidak dilakukan hanya sebatas pemenuhan tuntutan tertib administratif. Lebih jauh lagi, Sihaloho dan Halim (Sofyani \& Akbar, 2013) menilai bahwa niat penggunaan sistem pengukuran kinerja di sebagian besar institusi pemerintah lebih didominasi oleh tekanan luar. Artinya bahwa, pengukuran kinerja terkadang hanya untuk memenuhi kebutuhan pertanggungjawaban administratif. Tetapi esensi dari pengukuran kinerja tidak tercapai, sebab aparatur dan instansi pemerintah hanya mengejar formalisme belaka. Padahal jika ingin ditelaah lebih dalam, pengukuran kinerja adalah jantung untuk menilai kualitas pelayanan, akuntabilitas, efisiensi, efektifitas instansi pemerintah.

Dalam pengukuran Kinerja sebuah organisasi yang informal ataupun formal tentu memiliki standar dan kriteria masing-masing. Tergantung kepada objek dan subyek yang akan diukur kinerjanya. Prinsip pengukuran kinerja dapat dikategorikan menjadi dua. Cavaluzzo dan Ittner (Sofyani \& Akbar, 2013) mengemukakan faktor-faktor yang mempengaruhi keberhasilan implementasi sistem pengukuran kinerja: yaitu faktor teknis, meliputi kesulitan menentukan ukuran kinerja dan keterbatasan sistem informasi. Dan faktor organisasional, meliputi: komitmen manajemen, otoritas pembuatan keputusan, dan pelatihan. Artinya pengukuran kinerja harus komprehensif agar tidak terjadi kekeliruan sewaktu menilai sebuah instansi pemerintah. Jika dilakukan tanpa ada ukuran yang jelas, maka rekomendasi sebagai bagian dari sistem pengukuran kinerja bisa sangat buruk dan membahayakan intansi atau organisasi.

Pengukuran kinerja termasuk dalam standar untuk mengamati dinamika yang ada di sebuah organisasi atau instansi pemerintahan. Dwiyanto (Ariany \& Putera, 2013) mengemukakan beberapa indikator yang dapat digunakan dalam mengukur kinerja 
birokrasi pelayanan publik, yaitu: (1) Produktivitas. Konsep produktivitas tidak hanya mengukur tingkat efisiensi, tetapi juga efektivitas pelayanan; (2) Kualitas Layanan. Kepuasan masyarakat terhadap layanan dapat dijadikan indikator kinerja organisasi publik, sebab akses untuk mendapatkan informasi mengenai kualitas layanan relatif sangat mudah dan murah; (3) Responsivitas. Responsivitas dimasukan sebagai salah satu indikator kinerja karena responsivitas secara langsung menggambarkan kemampuan organisasi publik dalam menjalankan misi dan tujuannya, terutama untuk memenuhi kebutuhan masyarakat; (4) Responsibilitas. Responsibilitas menjelaskan apakah pelaksanaan kegiatan organisasi publik itu dilakukan sesuai dengan prinsipprinsip administrasi yang benar atau sesuai dengan kebijakan organisasi, baik yang eksplisit maupun implisit; (5) Akuntablitas. Konsep akuntabilitas publik dapat digunakan untuk melihat seberapa besar kebijakan dan kegiatan organisasi publik itu konsisten dengan kehendak masyarakat banyak.

Pendapat diatas mengidentifikasikan jika sistem pengukuran kinerja memiliki beberapa indikator. Setiap indikator itu memiliki sistem pengukurannya masing masing. Misalkan akuntabilitas yang menilai sejauh mana proses pertanggungjawaban dari instansi pemerintah kepada masyarakat tentang kebijakan yang telah dilakukan. Masyarakat perlu untuk mengetahui alokasi anggarannya berapa, jadwalnya kapan, dan juga prosesnya seperti apa. Komponen - komponen ini yang dipenuhi dalam indikator penilaian kinerja pemerintahan melalui indikator akuntabilitas. Begitupun dengan indikator-indikator lain dengan karakteristiknya. Tetapi semua komponen dan indikator itu hanya befungsi untuk menghasilkan pengukuruan kinerja yang komprehensif dari instansi pemerintahan.

Objek yang menjadi sasaran dalam penelitian ini adalah BUMDes Dile, sehingga peneliti merasa perlu menambahkan beberapa konsep atau teori tentang BUMDes. Badan Usaha Milik Desa, selanjutnya disebut BUM Desa, adalah badan usaha yang seluruh atau sebagian besar modalnya dimiliki oleh Desa melalui penyertaan secara langsung yang berasal dari kekayaan Desa yang dipisahkan guna mengelola aset, jasa pelayanan, dan usaha lainnya untuk sebesar-besarnya kesejahteraan masyarakat Desa (Permen No 4 Tahun 2015).

BUMDes merupakan pilar kegiatan ekonomi di desa yang berfungsi sebagai lembaga sosial (social institution) dan komersial (commercialinstitution). BUMDes sebagai lembaga sosial berpihak kepada kepentingan masyarakat melalui kontribusinya dalam penyediaan pelayanan sosial. Sedangkan sebagai lembaga komersial bertujuan mencari keuntungan melalui penawaran sumberdaya lokal (barang dan jasa) ke pasar. Dalam menjalankan usahanya prinsip efisiensi dan efektifitas harus selalu ditekankan. BUMDes sebagai badan hukum, dibentuk berdasarkan tata perundang-undangan yang berlaku, dan sesuai dengan kesepakatan yang terbangun di masyarakat desa. Dengan demikian, bentuk BUMDes dapat beragam di setiap Desa di Indonesia. Ragam bentuk ini sesuai dengan karakteristik lokal, potensi, dan sumberdaya yang dimiliki masingmasing desa. Pengaturan lebih lanjut tentang BUMDes diatur melalui Peraturan Daerah 
(Perda) (Buku Panduan Pendirian Dan Pengelolahan Badan Usaha Milik Desa (BUMDes), 2007).

Peneliti mengakui ada banyak konsep dari pengukuran kinerja. Tetapi dalam kasus ini, peneliti berfokus pada pendekatan penilaian kinerja yang dimotori oleh. Pendapat dari kedua ahli tersebut menjadi konsep utama yang dijadikan sebagai pisau analisa untuk memahami faktor apa saja yang mempengaruhi kinerja BUMDes Dile. Donald S. Van Meter dan Carl E. Van Horn (Puwanto, Agus \& Ratih, 2015) menjelaskan terdapat lima (5) variabel yang mempengaruhi kinerja implementasi. Pertama, standar dan sasaran kebijakan harus jelas terukur sehingga dapat direalisasikan. Apa bila standar dan sasaran kebijakan kabur, maka akan terjadi multiintepretasi dan mudah menimbulkan konflik di antara agen implementasi. Kedua, Implementasi kebijakan perlu dukungan sumberdaya baik manusia ( human resources) maupun sumberdaya non-manusia (non-human resources). Ketiga, Hubungan antar organisasi. Dalam banyak program, implementasi sebuah program perlu dukungan dan koordinasi dengan instansi lain. Untuk itu, diperlukan koordinasi dengan instansi lain. Untuk itu, diperluakan koordinasi dan kerjasama antar instansi bagi keberhasilan suatau program. Keempat, Karakteristik agen pelakasana. Yang dimaksud karakteristik agen pelaksana adalah mencakup struktur birokrasi, norma-norma, dan pola-pola hubungan yang terjadi dalam birokrasi, yang semuanya itu akan memengaruhi implementasi suatau program. Kelima, Kondisi sosial, politik, dan ekonomi. Variabel ini mencakup sumberdaya ekonomi lingkungan yang dapat mendukung keberhasilan implementasi kebijakan; sejauhmana kelompk-kelompok kepentingan memberikan dukungan bagi implementasi kebijakan; karakteristik para partisipan, yakni mendukung atau menolak; bagaimana sifat opini publik yang ada dilingkungan; dan apakah elite politik mendukung implementasi kebijakan.

Adapun penelitian terdahulu yang serupa dengan penelitian ini. Penelitian tersebut ditulis oleh Alif Bus Reyndra dengan judul penelitian "faktor-faktor yang mempengaruhi kinerja badan usaha milik desa" (Rendra, 2018). Penelitian ini menggunakan pendekatan studi kasus dan dilakukan di dua desa yaitu Desa Panggungharjo dan Desa Wonokromo. Faktor -faktor yang mempengaruhi kinerja BUMDes berdasarkan penelitian tersebut adalah pertama, kepimpinan yang harus memiliki kualitas manajerial untuk bisa menjalankan BUMDes. Kedua, Sumber Daya Manusia yang diukur dari kemampuan pegawai dalam menjalankan kewajiban dan tanggungjawab. Keterampilan juga belum begitu terasah, meskipun penyuluhan telah diberikan. Jumlah penguruh BUMDes juga tidak sesuai dengan kebutuhan, seperti yang terjadi di BUMDes Wonokromo. Ketiga, komunikasi yang dibangun baik antara BUMDes dan pemerintah Desa atau BUMDes dengan masyarakat. Komunikasi ini, saah satunya dibangun dengan memberikan trasparansi dan penyuluhan tentang program-program BUMDes yang ingin dijalankan.

Kebaharuan yang membedakan penelitian ini dengan penelitian terdahulu pertama terletak pada posisi pengambilan teori. Teori yang digunakan peneliti menfokuskan pada standar dan sasaran kebijakan, sehingga kinerja BUMDes bisa diukur melalui 
bagaimana kebijakan tersebut diimplementasikan. Kedua, sumber daya yang tidak hanya dilihat dari sisi kompetensi pengurus BUMDesnya saja, melainkan meninjau juga kesiapan sumber daya alammnya, apakah bisa diproduksi atau dimanfaatkan untuk mendukung pendapatan BUMDes. Selain dukungan sumber daya alam, kinerja BUMDes juga dapat diteropong dari suplai finansial serta sarana dan prasarana. Karena kedua hal tersebut berguna untuk mengoperasikan segala bentuk kegiatan yang ingin dijalankan BUMDes. Sedangkan yang terakhir adalah kondisi sosial yang dititiberatkan kepada respon masyarakat dalam mendukug BUMDes. Karena dukungan masyarakat ini sangatlah penting agar BUMDes tidak menjadi murni perusahaan yang hanya mengejar keuntungan, melainkan BUMDes hadir untuk memberdayakan masyarakat setempat. Sedangkan untuk karakteristik agen pelaksana dan hubungan antara organisasi, menurut peneliti tidak jauh berbeda dari penelitian sebelumnya.

Kedua, hasil dan temuan dilapangan juga berbeda didasarkan pada lokasi penelitian dan juga keadaan masyarakat yang memang berbeda antara penelitian sebelummnya. Penelitian ini dilakukan di Desa Dile, Kabupaten Ende yang hampir sebagian besar pemahaman masyarakat tentang pentingnya BUMDes belum begitu merata. Selain itu kepengurusan BUMDes sebagaian besar dibentuk secara spontan sebagai bentuk paksaan dari pemerintah Kabupaten Ende untuk memuluskan jalannya UU Desa. Sehingga berdampak kepada kinerja BUMDes yang memang belum begitu maksimal karena penyiapan potensi sumber daya manusiannya, proses penyadaran kepada masyarakat, dan juga BUMDes harus bersaing dengan usaha- usaha yang sudah dirintis masyarakat Desa.

\section{Metode Penelitian}

Penelitian ini menggunakan metode penelitian deskriptif kualitatif. Metode penelitian kualitatif menggunakan lingkungan alamiah, dimana penelitian dilakukan pada situasi alamiah dalam suatu keutuhan agar sumber data yang di dapat secara langsung bersifat naturalistik, tidak manipulatif dan terbuka pada apapun yang akan timbul ke depan (Simangunsong, 2016). Teknik pengumpulan data yang digunakan dalam penelitian ini, yaitu observasi, wawancara, dan dokumentasi. Data tesebut dikumpulkan dari berbagai informan dan selanjutnya dilakukan proses analisa. Teknis analisis data menggunakan model Miles dan Huberman (Simangunsong, 2016) yang dilakukan secara interaktif terdiri dari reduksi data (data reduction), penyajian data (data display), dan conclusion Drawing/Verification.

\section{Hasil dan Pembahasan}

\section{A. Standar dan Sasaran Kebijakan}

Standar dan Sasaran menjadi awal dalam proses pelaksanaan kebijakan. Sebelum kebijakan dilaksanakan, kebijakan tersebut harus dirumuskan dengan capaian-capaian yang dibutuhkan. BUMDes Dile di bentuk pada tahun 2016 dengan acuan dan tuntutan dari Pemerintah Daerah Ende melalui (Peraturan Daerah Kabupaten Ende, 2014). PERDA tersebut menginstrusikan bahwa setiap Desa yang 
ada di Kabupaten Ende wajib memiliki BUMDes. Standar kebijakan ada melalui PERDA Ende, sehingga pemerintah Dile membentuk BUMDes. Proses perumusan itu salah satunya memilih pengurus BUMDes, tetapi dalam perjalanan pengurus tidak dilantik yang mengakibatkan pelaksanaan kegiatan dan kebijakan untuk mengembangkan BUMDes tidak direalisasikan. Standar dan visi akhirnya menjadi kabur yang berakibat pada BUMDes berjalan di tempat. Secara kepengurusan belum menemukan titik terang, padahal seharusnya persoalan pengurus harus sudah selesai. Pengurus inilah yang akan menjadi motor penggerak BUMDes. Terkait standar dan sasaran ini Van Meter dan Van Horn menjelaskan bahwa apa bila standar dan sasaran kebijakan kabur, maka akan terjadi multiintepretasi dan mudah menimbulkan konflik di antara para agen implementasi. Hal demikian terjadi pada polemik BUMDes Dile ketika pembentukan awal. Pengurus yang dipilih secara aklamasi tidak memiliki SK kepengurusan. Ketidakjelasan proses administratif ini selanjutnya mempengaruhi proses pengerjaan unit-unit usaha yang sudah disepakati. Bahkan sampai pada realisasi anggaran yang tersendat-sendat dikarenakan proses pertanggungjawaban harus membutuhkan pengurus yang secara aturan legal. Tetapi jika itu tdak ada, maka proses pertanggungjawaban menjadi terhambat. Meskipun pengurus telah diganti, tetapi laporan pertanggungjawaban pada periode tidak ada realisasi.

Terkait dengan unit usaha yang menjadi pilihan dan standar untuk dikelola, BUMDes Dile memiliki tiga (3) program unit usaha:

Tabel 1

Pogram Unit Usaha BUMDes Dile

\begin{tabular}{ccc}
\hline No & Unit Usaha & Status \\
\hline 1 & Koperasi & Tidak Beroperasi \\
\hline 2 & $\begin{array}{c}\text { Pengadaan Barang dan Jasa (tenda dan } \\
\text { kursi) }\end{array}$ & Beroperasi \\
\hline 3 & Pembelian Komoditi & Tidak Beroperasi \\
\hline & Data: di olah dari profil Bumdes, 2016
\end{tabular}

Program tabel 1 adalah unit usaha yang telah disepakati dalam MUSDes (Musyawarah Desa) untuk menentukan jenis-jenis usaha yang dibutuhkan oleh masyarakat dan disesuaikan dengan potensi lokal yang ada. Artinya standar dan sasaran yang ingin dicapai sudah ada melalui program unit usaha BUMDes. Tetapi pada kenyataannya hanya satu (1) unit usaha yang benar-benar berjalan. Kedua unit usaha lain, yaitu koperasi dan pembelian komoditi tidak berjalan. Tidak berjalannya unit usaha itu dikarenakan penyertaan modal 50 juta hanya dialokasikan untuk unit usaha pengadaan barang dan jasa (kursi dan tenda). Hal lain juga terjadi polemik internal antara pengurus BUMDes dan pemerintah desa karena pelaporan yang tidak dibuatkan. 


\section{B. Sumber Daya}

Implementasi program kerja tentunya membutuhkan dukungan sumber daya yang memadai, baik sumber daya manusia atau sumber daya finansial dan SARPRAS. Secara infratruktur bangunan, BUMDes Dile belum memiliki dan masih menggunakan kantor pemerintah desa untuk aktivitas. Anggaran untuk pembangunan kantor BUMDes sampai saat ini tidak pernah ada, apa lagi dengan polemik internal yang belum terselesaikan membuat pembahasan pembangunan kantor dihentikan sementara. Sebagian besar aktivitas diskusi dan perencaan program BUMDes dilakukan di rumah ketua BUMDes. Memang secara prosedur pemandangan ini tidak elok dikarenakan bisa saja terjadi politisasi kegiatan atau program. Sumber daya berikut yang mendukung program - program di unit usaha BUMDes Dile adalah Sumber Daya Alam. Data berikut ini akan membantu menjawab alasan mengapa unit usaha pembelian komoditi masuk dalam program BUMDes, meskipun realisasinya tidak dijalankan.

\section{Tabel 2}

Data Komoditi Desa Dile

\begin{tabular}{ccc}
\hline No & Uraian & Luas/Ha \\
\hline 1 & Kemiri & $33 \mathrm{Ha}$ \\
\hline 2 & Kopi & $5 \mathrm{Ha}$ \\
\hline 3 & Cengkeh & $1,5 \mathrm{Ha}$ \\
\hline 4 & Kakao & $1,5 \mathrm{Ha}$ \\
\hline 5 & Padi Sawah & $13,5 \mathrm{Ha}$ \\
\hline
\end{tabular}

Suber: Data profil Desa Dile

Data tabel 2 sebenarnya menunjukkan alasan mendasar mengapa unit usaha komoditi perlu ada di dalam tubuh BUMDes. Penentuan unit-unit usaha dilakukan di dalam musyawarah Desa dengan mempertimbangkan potensi lokal. Tetapi dalam perjalanannya, unit usaha komoditi ini tidak berjalan. Banyak tantangan yang di hadapi, misalkan berbenturan dengan usaha-usaha masyarakat yang memang konsentrasinya pada jual beli komoditi. Berdasarkan literatur, seharunya BUMDes hadir tidak mematikan usaha-usaha yang sudah ada di tengah masyarakat. Sebaliknya BUMDes harus membantu agar unit usaha yang sudah dirintis masyarakat tetap eksis dan terus berjalan.

Sebagian besar potensi lokal yang ada di Dile adalah kemiri. Tetapi masyarakat tidak menjual ke BUMDes, melainkan langsung ke pengumpulpengumpul yang ada di Desa atau langsung di jual ke Kota. Metode penjualan ini berimbas kepada penentuan harga yang hanya ditentukan sepihak oleh pengumpul atau tempat masyarakat menjual komoditi. Sebenarnya ini memberatkan masyarakat dengan kondisi harga yang tidak selalu stabil, terkadang masyarakat terpaksa langsung menjual hasil panen kemirinya. Meskipun mereka tahu bahwa harga yang ditawarkan tidak sesuai dengan ekspetasi mereka. Sehingga bisa dilihat jika perputaran ekonomi pedesaan tidak ditentukan oleh masyarakat sendiri, 
melainkan oleh aktor-aktor lokal yang notabenenya adalah orang-orang yang mendedikasikan dirinya sebagai perantara penjualan hasil kemiri/komoditi. Celah inilah yang seharunya diisi oleh BUMDes untuk meningkatkan ekonomi masyarakat. Tetapi hasilnya nihil, karena BUMDes Dile masih sibuk dengan urusan-urusan internal dan administratif yang belum juga selesai.

Sumber Daya Manusia juga menjadi salah satu point dalam pengelolahan BUMDes. Oleh karena itu, kinerja BUMDes Dile tidak semata - mata hanya melihat komposisi sumber daya alamnya saja. Tetapi juga harus meneropong bagaimana kesiapan dan infrastruktur manusianya. Di dalam regulasi dijelaskan bahwa pengurus BUMDes minimal berijazah SMA. Data berikut ini akan menjelaskan komposisi pengurus BUMDes Dile dari perspektif kepemilikan ijazah terakhir.

Tabel 3

Profil Pengurus BUMDes

\begin{tabular}{cccc}
\hline No & Nama & Jabatan & $\begin{array}{c}\text { Pendidikan } \\
\text { Terakhir }\end{array}$ \\
\hline 1 & Ibrahim Pay & Ketua BUMDes & SMA \\
\hline 2 & Hendrikus Mesi & Sekretaris & SMA \\
\hline 3 & Nikolaus Sae & Bendahara & SMA \\
\hline
\end{tabular}

Sumber: data diolah dari hasil penelitian

Data tabel 3 menunjukkan bahwa syarat ijazah terakhir memang terpenuhi, tetapi yang menjadi persoalan adalah kepengurusan ini tidak memiliki legitimasi. Karena masih belum memilki SK yang sah. Ditambah lagi dengan pembagian pekerjaan yang tidak maksimal karena dilapangan segala macam urusan hanya di jalankan oleh ketua BUMDes. Pengurus BUMDes lain terkesan tidak mengerjakan TUPOKSI nya untuk mengelola BUMDes. Dan kepengurusan ini sangat minim dikarenakan koordinator dari masing-masing unit belum ada, sehingga pengelolahan unit-unit usaha masih ditangani oleh pengurus inti.

\section{Hubungan Antar Organisasi}

Pelaksanaan program kerja tidak hanya di jalankan oleh satu unit/organisasi saja. Secara ideal setiap pencapaian implementasi program kerja yang baik selalu berasal dari koordinasi antara satu unit dengan unit yang lain atau organisasi dengan organisasi yang lain. Ini juga berlaku untuk BUMDes dile yang membutuhkan dukungan dari unit/organisasi lain yang ada di Desa.

Dari beberapa kutipan wawancara ditemukan bahwa koordinasi dan kerjasama antara BUMDes dengan organisasi terkait seperti pemerintah desa, BPD, dan masyarakat yang ada di Desa berjalan dengan baik. Tetapi pada kenyataannya, BUMDes Dile "mati suri” dari tahun 2018 sampai sekarang. Fakta ini menunjukan bahwa memang ada ketidakberesan secara internal dala mengelola BUMDes Dile. Mulai dari belum adanya SK pengurus, pergantian pengurus yang tidak transparan, dan pelaporan keuangan BUMDes yang masih tersendat-sendat. Artinya bahwa, 
masing-masing organisasi di desa yang seharusnya mampu mengontrol kinerja BUMDes tidak juga berjalan semestinya. Atau sebaliknya bahwa BUMDes "enggan" untuk inklusif dengan organisasi atau unit lain yang ada di desa. Yang pada akhirnya membuat BUMDes Dile berjalan ditempat.

\section{Karakteristik Agen Pelaksana}

Temuan paling menonjol dari indikator ini adalah program pelatihan yang tidak berjalan dan kesesuain program pelatihan dengan orang yang dipilih. Pengembangan sumber daya manusia pernah dibuat ketika BUMDes Dile selesai di bentuk pertama kali. Pelatihan itu langsung berada di bawah pemerintah daerah melalui Badan Pemberdayaan Masyarakat dan Desa (BPMD) kala itu dan sekarang sudah berubah menjadi Dinas. Program pelatihan ini bertujuan untuk mengelola BUMDes sesuai dengan kaidah-kaidah regulasi agar BUMDes menjadi pilar ekonomi pedesaan. Untuk mencapai itu, maka kebutuhan akan komposisi pengurus mulai dari keterampilan, skill, kualitas, dan lain -lain menjadi kunci dari pelatihan itu. Tetapi sayangnya, program ini tidak diikuti oleh pengurus BUMDes yang telah di pilih melainkan utusan tersebut berasal dari perangkat Desa.

Kesalahan ini berimbas kepada kinerja BUMDes dile yang membuat pengurusnya kebingunan untuk melakukan sesuatu. Fakta ini menunjukan bahwa secara organisasi antar BUMDes dan pemerintah desa sebenarnya tidak dijalankan secara harmonis. Ada rasa tidak saling percaya antara satu organisasi dengan organisasi lain. Yang kemudian berimbas pada banyak hal yang berkaitan dengan pengembangan BUMDes Dile untuk menjadi pilar ekonomi dan sosial di Desa.

\section{E. Kondisi Sosial}

Secara umum keterlibatan masyarakat Desa sudah kelihatan semenjak sosialisasi dilakukan oleh pemerintah desa untuk mendirikan BUMDes. Antusias masyarakat desa ini tidak datang dari kekosongan, melainkan mereka berharap bahwa kelak BUMDes benar-benar dapat membantu dari sisi ekonomi maupun sosial. Program yang ditawarkan pun berasal dari potensi lokal yang sangat di buhtukan oleh masyarakat, seperti jual beli komoditi, pengadaan kursi dan tenda jadi, dan perkiosan. Tiga hal pokok itu melekat pada kehidupan sehari-hari masyarakat desa Dile.

Pengembangan BUMDes Dile tentunya harus menyentuh aspek sosial dan ekonomi masyarakat. Hal ini menjadi penting dikarenakan kedua aspek tersebut adalah konsekuensi logis dari setiap kebijakan yang diambil oleh pemerintah Desa. Biasanya, kepercayaan masyarakat timbul jika sebuah program menyentuh kedua aspek itu. Proses sosialisasi memang harus dilakukan, tetapi disisi lain tidak boleh hanya sebatas pada level sosialisasi. Harus implementasi yang nyata oleh BUMDes agar kesejahteraan bisa dirasakan masyarakat Desa Dile. Tetapi kalau hanya sebatas sosialisasi, tentunya tidak akan memecahkan masalah masyarakat. Apa lagi mengurangi ketidakpercayaan masyarakat.

Kepercayaan masyarakat tidak hanya timbul dari aspek ekonomi dan sosial, tetapi juga aspek politik. Aspek ini terkait dengan pemahaman masyarakat 
terhadapa pentingnya BUMDes. Pemahaman menjadi penting agar masyarakat bisa dengan cerdas menyampaikan aspirasi mereka. Selain itu, masyarakat akan lebih sering bekerjasama dengan BUMDes karena akan menguntungkan dan bukan merugikan. Masih ada sebagaian masyarakat yang beranggapan bahwa BUMDes tidak menguntungkan mereka, apa lagi secara ekonomis. Padahal BUMDes hadir bukan sekedar mencari untung, melainkan mengembangkan ekonomi kolektif agar setiap masyarakat di Desa dapat sejahtera. Baik dari aspek sosial, politik, dan ekonomi.

\section{Kesimpulan}

Temuan-temuan dalam penelitian ini mengindikasikan bahwa pengelolahan BUMDes Dile belum begitu optimal baik secara organisasi maupun administratif. Ini menjadi pekerjaan rumah tidak hanya pengurus BUMDes, melainkan juga seluruh stekholders yang ada di desa untuk membantu dari berbagai aspek agar BUMDes tersebut dapat berjalan sesuai relnya. Bisa saja ada renovasi yang dilakukan untuk menghasilkan manejemen pengelolahan BUMDes yang lebih baik. Karena sampai hari ini BUMDes Dile masih belum menunjukan eksistensinya agar masyarakat percaya bahwa tujuan hadirnya BUMDes untuk membantu masyarakat baik secara ekonomi dan sosial. Tapi dengan keadaanya sekarang membuat masyarakat sedikit mengurangi kepercayaannya kepada BUMDes. 
Faktor-Faktor yang Mempengaruhi Kinerja BUMDES Dile dalam Pengelolahan Unit-

Unit Usaha

\section{BIBIOGRAFI}

Aini, Nurul. (2020). Gambaran Kinerja Badan Usaha Milik Desa (BUMDes) di Kabupaten Pati. Jurnal Litbang Provinsi Jawa Tengah, 18(2), 2.

Andri Donal Putera. (2018). "Alokasi Dana Untuk Tahun 2019 Akan Dinaikan”, diakses dari.

Ariany, Ria, \& Putera, Roni Ekha. (2013). Analisis Kinerja Organisasi Pemerintah dalam Memberikan Pelayanan Publik di Kota Pariaman. MIMBAR: Jurnal Sosial Dan Pembangunan, 29(1), 33-40. Google Scholar

Buku Panduan Pendirian Dan Pengelolahan Badan Usaha Milik Desa (BUMDes). (2007). Departemen Pendidikan Nasional, Pusat Kajian Dinamika Sistem Pembangunan (PKSDSP), Fakultas Ekonomi Universitas Brawijaya, Malang.

Firmansyah. (2018). "2019, Desa Diharapkan Dapat Dana Hingga Rp 1,3 Miliar Per Tahun”, diakses dari.

Hardiyansyah, Hardi. (2013). Sistem Administrasi dan Manajemen Sumber Daya Manusia Sektor Publik dalam perspektif otonomi daerah. Yogyakarta: Gava Media. Google Scholar

Madjodjo, Farid, \& Dahlan, Fadli. (2020). Analisis kinerja Badan Usaha Milik Desa dalam pengelolaan anggaran untuk meningkatkan pengolahan potensi desa di Desa Akedotilou. Indonesia Accounting Journal, 2(2), 187-195. Google Scholar

Peraturan Daerah Kabupaten Ende. (2014). No 7 tentang pedoman dan pembentukan pengelolahan Badan Usaha Milik Desa.

Puwanto, Agus \& Ratih, Dyah. (2015). Implementasi Kebijaan Publik (Konsep dan Aplikasinya Di Indonesia). Yogyakarta: Gava Media. Google Scholar

Raihanah Daulay, Efri Kurnia, Irvan Maulana. (2019). Analisis Faktor - Faktor Yang Mepengaruhi Kinerja Karyawan Pada Perusahaan Daerah Di Kota Medan. Sumatra Utara, Indonesia: Proseding Seminar Nasional Kewirausahaan, Fakultas Ekonomi dan Bisnis Universitas Muhammadiyah Sumatra Utara.

Rendra, Alif Bus. (2018). "Faktor-Faktor Yang Mempengaruhi Kinerja Badan Usaha Milik Desa (studi kasus di BUMDes Panggugharjo, Kecamatan Sewon dan BUMDes Wonokromo, Kecamatan Pleret." Universitas Muhammadyah Yogyakarta. Retrieved from http://repository.umy.ac.id/handle/123456789/29281

Riant, Nugroho. (2012). Public Policy: Dinamika Kebijakan, Analisis Kebijakan, Manajemen Kebijakan. Jakarta, Elex Media Komputindo. Google Scholar

Simangunsong, Fernandes. (2016). Metodologi Penelitian Pemerintahan. Alfabeta, Bandung. Google Scholar 
Fidentus Didakus Darma Saputra

Sofyani, Hafiez, \& Akbar, Rusdi. (2013). Hubungan faktor internal institusi dan implementasi sistem akuntabilitas kinerja instansi pemerintah (SAKIP) di Pemerintah Daerah. Jurnal Akuntansi Dan Keuangan Indonesia, 10(2), 184-205. Google Scholar

Suharto, Edi. (2015). Analisis kebijakan publik: panduan praktis mengkaji masalah dan kebijakan sosial. Google Scholar

Wahyuni, Endang Sri, Taufik, Taufeni, \& Ratnawati, Vince. (2016). Pengaruh budaya organisasi, locus of control, stres kerja terhadap kinerja aparat pemerintah daerah dan kepuasan kerja sebagai variabel intervening (Studi empiris pada Pemerintah Kabupaten Bengkalis). Jurnal Manajemen, 20(2), 189-206. Google Scholar

\section{Copyright holder:}

Fidentus Didakus Darma Saputra (2021)

First publication right:

Syntax Literate: Jurnal Ilmiah Indonesia

This article is licensed under:

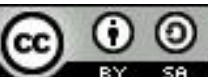

